\title{
KAJIAN PUISI JERMAN MELALUI METODE SEMIOTIK
}

\author{
Jolanda Tomasouw
}

\author{
Email: marland_mt@yahoo.co.id \\ FKIP Universitas Pattimura Jurusan Pendidikan Bahasa dan Seni \\ Alamat Korepondensi: Batu Gantung Ganemo No. 17/14 Ambon 97116
}

\begin{abstract}
As one type of literature, poetry, the unit called a rhyme, is the most unique genre. The uniqueness is due to all forms of expression that stick out in rhyme. In contrary to other literary works such as short stories, novels, or plays, poems written succinctly in the form of stanza and line. Due to the density of the message to be conveyed in such a confined space, then the choice of words and forms of writing that used very unique and complex elements by accentuating of poetic sense. That means, understanding a poem as a form of literary works the same as dealing with the texts of poems that are strung in a poetic language different with language in general. The uniqueness of the language used in the poem appeared on the use of symbols words that are figurative and the use of a distorted form of writing. Deviation form is for example the accentuation of cutting sentences or lines unreasonably, the use of words and sounds are repetitive, the use of words by imitating certain sounds or the use of meaningful associative words excessively. Modern German poetry lies in the harmony of the poetic elements that build a rhyme. Thus the resulting of rhyme and diction values and its imagery is based on how the elements that form the building of rhyme which is coherent and intact. The process of reading poetry in the context of semiotic dialectic is a process of giving meaning to a text of modern poetry through a text search in order to find the code or semiotic signs.
\end{abstract}

\section{Keywords}

Puisi Jerman, Modern, Semiotika

\section{Pendahuluan}

Pengkajian puisi melalui analisis yang sesuai merupakan upaya yang seharusnya dilakukan untuk membantu pembaca sastra modern memahami karya sastra. Memahami teks sastra terjadi karena ada alasan bahwa memahami teks sastra tidaklah semudah memahami teks non sastra. Jika pemahaman teks non sastra tergantung pada kemampuan pembaca memahami perpaduan antara kesatuan gramatikal dan kesatuan makna, baik makna kata maupun makna kalimat yang terikat pada situasi dan konteks tertentu, maka pemahaman sastra modern memerlukan pengetahuan sistem kode atau konvensi yang cukup rumit dan kompleks, baik kode bahasa, kode budaya maupun kode sastra yang khas dan terkadang menyimpang dari kaidah penulisan teks non sastra dalam sistem kebahasaan bahasa tertentu.

Sejalan dengan perkembangan kehidupan masyarakat dunia yang sekaligus juga mempengaruhi nilai-nilai budaya masyarakat kea rah modernisasi, karya sastra khususnya puisi juga berkembang. Jika puisi lama sangat terikat pada bentuk penulisan yang disusun dalam alur irama, dengan menggunakan persajakan pola baku tertentu, seperti $a-b-a-b$ atau $a-a-a-a$ serta, secara tipografis juga dibentuk dengan bentuk larik dan bait yang sekaligus merupakan ciri visual puisi, maka puisi modern sangat bebas diekspresikan oleh para penciptanya sebagai bentuk pencarian kebebasan pengungkapan pribadi. Sebagai bentuk ekspresi pribadi yang bebas, tentu saja puisi modern tidak mengutamakan adanya pola estetika yang kaku sebagai mana pada puisi lama. Artinya, bagi puisi modern tidak berlaku ketentuan mengenai jumlah bait, pola persajakan tertentu, jumlah larik dalam setiap bait dan sebagainya.

Hal utama yang menjadi ketentuan umum puisi modern terletak pada unsur-unsur kepuitisan yang membangun sebuah sajak. Dengan demikian nilai rima,nilai diksi dan jalinan citraan yang dihasilkan didasarkan pada bagaimana unsure-unsur itu membentuk bangunan sajak yang padu dan utuh. Penggunaan bentuk bahasa atau kata untuk memadukan unsure-unsur tersebut merupakan suatu bentuk system tingkat kedua yang menggunakan medium bahasa yang merupakan system tanda tingkat pertama. Dengan demikian 
pengungkapan makna dalam puisi modern tidak hanya didasari pada tanda-tanda bahasa secara normatif saja, tetapi juga memperhatikan konvensi-konvensi tambahan yang memberi makna tertentu.

Adanya karakteristik bentuk puisi modern yang khas menandai adanya sistem semiotik tingkat kedua dan ini dapat menjadi hambatan dan sekaligus menimbulkan kesulitan tersendiri bagi pembaca puisi. Khusus bagi pembaca yang awam dalam tindak pembacaan sebuah puisi, pencarian makna puisi dipahami sebagai sebuah proses komunikasi antara pembaca dan teks yang oleh Riffaterre (1984:1) disistilahkan sebagai "dialektika semiotik" antara pembaca dan teks. Untuk itu, pembaca harus memahami adanya perbedaan secara empiris antara teks yang mengandung unsure puitis dan bahasa literature yang digunakan adalah cara suatu teks puisi membawa makna. Artinya proses membaca puisi dalam konteks dialektika semiotik merupakan proses pemberian makna pada sebuah teks puisi modern melalui penelusuran teks secara mendalam untuk menemukan kode atau tandatanda semiotik. 


\section{Penutup}

Proses pengkajian puisi Jerman modern melalui metode semiotik mengutamakan dua cara membaca yakni pembacaan heuristik dan pembacaan heuristik. Cara yang pertama, mencoba membantu pembelajar memahami sebuah sajak pada level mimesis (konvensi bahasa). Sementara teknik kedua menganalisis sajak untuk mengungkapkan makna pada level tinggi yakni pemahaman konvensi sastra. Hasil analisis pada level pertama kemudian dikaitkan dengan pemahaman pada tingkat kedua untuk memperoleh pemahaman keseluruhan sajak dimaksud. Metode semiotik juga bertujuan untuk memberi gambaran secara lengkap, dan menyeluruh tentang makna sebuah puisi, melalui kajian yang mendalam terhadap semua unsure pendukung puisi. Hasil kajian makna setiap unsur pendukung tersebut kemudian dihubungkan dengan konvensi-konvensi sastra dan non sastra melalui kajian semiotik.

\section{DAFTAR PUSTAKA}

Altenbernd. Lynn, and Leslie L. Lewis. 1970. A Handbook for the Study of Poetry. London: The Macmillan Company.

Aminudin. 1995. Stilistika Pengantar Memahami Bahasa Dalam Karya Sastra. Semarang: Penarbit CV. IKIP Semarang Press.

Blanke, H., Gustav. 1973. Einfũhrung in die Semantische Analyse. Mũnchen: Max Hueber Verlag.

Gross, Harro. 1988. Einfuhrung in die Germanistische Linguistik. Muenchen: Iudicium Verlag.

Hermes, Eberhard. 1995. Abiturwissen Lyrik. Stuttgart: Ernst Klett Verlag fuer Wissen und Bildung.

Hill, Knox, C. 1966. Interpreting Literature. Chicago: Chicago University Press.

Moody, H., L., B. 1971. The Teaching of Literature with Special Reference to Developing Countries. London: Longman Group LTD.

Nöth, Winfried. 1990. Hanbook of Semiotics. Bloomington and Indianapolis: Indiana University Press.

Nurgiyantoro, Burhan. 2002. Teori Pengkajian Fiksi. Yogyakarta: Gajah Mada University Press.

Pradopo, Rachmat Djoko. 2003. Beberapa Teori Sastra, Metode Kritik dan Penerapannya. Yogyakarta: Penerbit Pustaka Pelajar, 2003.

1999. Pengkajian Puisi. Yogyakarta: Gadjah Mada University Press.

Richards, I. A. 1976 Practical Critiism. London: Routledge \& K. Paul, 1976.

Riffaterre, Michael. 1984. Semiotics of Poetry. Bloomington-London: Indiana University Press.

Sudjiman, Panuti. dan Aart Van Zoest, (ed). 1996. Serba-Serbi Semiotika. Jakarta: Penerbit PT Gramedia Pustaka Utama.

Teeuw, A. 1984. Sastra dan Ilmu Sastra. Pengantar Teori Sastra. Jakarta: Pustaka Jaya.

1991. Membaca dan Menilai Sastra. Jakarta: PT. Gramedia.

Waldmann, Günter. 1996. Produktiver Umgang mit Lyrik, Eine Systematische Einfuhrung in der Lyrik, Ihre Produktive Erfahrung und Ihr Schreiben. Göppingen: Schneider Verlag Hohengehren GmbH.

Waluyo, Herman. 1991. Teori dan Apresiasi Puisi. Jakarta: Penerbit Erlangga.

2002. Apresiasi Puisi. Panduan untuk Pelajar dan Mahasiswa. Jakarta: Penerbit PT. Gramedia Pustaka Utama. 
Wirjosoedarmo, Soekono. 1994. Pengantar ke Arah Studi Teori Sastra Indonesia. Jember: PT. Intan. 